\title{
SENAM IRAMA LAGU GIZI SEIMBANG MENINGKATKAN KEBUGARAN PADA ANAK SEKOLAH
}

\author{
Een Juliasti ${ }^{1}$, Mury Kuswari ${ }^{* 2}$ dan Idrus Jus'at ${ }^{3}$ \\ Universitas Esa Unggul, Indonesia ${ }^{1,2,3}$ \\ Asosiasi Nutrisionis Olahraga dan Kebugaran Indonesia (ANOKI) ${ }^{2,3}$ \\ Email: juliastieen@ gmail.com ${ }^{* 1}$, mury@ esaunggul.ac.id ${ }^{* 2}$, idrus.jusat@ esaunggul.ac.id ${ }^{3}$
}

Received: 07 November 2019; Accepted 07 May 2020; Published 04 June 2020

Ed 2020; 5(1): 22-29

\begin{abstract}
ABSTRAK
Aktivitas fisik pada anak sekolah di Jakarta terdendah apabila dibandingkan berbagai daerah di Indonesia. Rendahnya aktivitas fisik berdampak pada menurunnya kesehatan dan kebugaran sehingga berpengaruh terhadap resiko berbagai macam penyakit tidak menular. Tujuan penelitian untuk mengetahui pengaruh senam irama lagu gizi seimbang terhadap tingkat kebugaran pada anak sekolah di SD Negeri Kebon Jeruk 08 Pagi Jakarta Barat. Jenis penelitian yang digunakan adalah penelitian quasi eksperimental dengan bentuk desain pretest - posttest control group, dengan desain ini melibatkan dua kelompok subjek, satu diberi pelakuan (kelompok eksperimen) dan satu kelompok tidak diperlakuan (kelompok kontrol). Populasi penelitian ini adalah anak yang berusia 10-12 tahun sebanyak 60 responden (30 siswa kelompok senam dan 30 siswa kelompok kontrol) dengan senam 3x/minggu selama 12 kali. Analisa data menggunakan Uji t dependen, wilcoxon test karena data berdistribusi tidak normal. Hasil Penelitian menunjukan ada pengaruh senam irama lagu gizi seimbang terhadap tingkat kebugaran signifikan ( $p$ value =0,0001). Kesimpulan dalam penelitian ini menunjukkan bahwa latihan senam gizi seimbang meningkatkan kebugaran dibandingkan dengan kelompok kontrol pada anak sekolah di SD Negeri Kebon Jeruk 08 Pagi Jakarta Barat.
\end{abstract}

Kata Kunci: Senam Irama; Gizi Seimbang; Kebugaran; Anak Sekolah

\section{RHYTHMIC GYMNASTICS WITH GIZI SEIMBANG'S SONG INCREASES THE LEVEL OF FITNESS ON STUDENTS}

\begin{abstract}
Physical activity on students in Jakarta is the lowest if it is compared to various regions in Indonesia. The low physical activity has an impact on the declining of health and fitness so that it affects toward the risk of various non-communicable diseases. The purpose of this research is to know the influence of gymnastics rhythm of Gizi Seimbang's song to the level of fitness on students in State Elementary School Kebon Jeruk 08 Pagi West Jakarta. The type of research uses design experimental quasi research with design of Pre test - post test group control design. This design involves two groups of subjects, one is given an experimental group and one group is not enforced (control group). The population of this study are children aged 10-12 years old with 60 respondents (30 students of gymnastic group and 30 control group students) with gymnastics $3 x /$ week for 12 times. Data analysis use t-dependent test, wilcoxon test because the data is not normally distributed. The result of the research shows that there is the influence of rhythmic gymnastics of Gizi Seimbang's song to the significant fitness level ( $p$ value $=0.0001$ ). Based on the results of this study, gymnastics rhythm of Gizi Seimbang's song increases the level of fitness compared with control group on students in State Elementary School Kebon Jeruk 08 Pagi West Jakarta.
\end{abstract}

Keywords: Rhythmic Gymnastics; Balanced Nutrition; Fitness; School Children

Copyright @ 2020, Journal Sport Area

DOI: https://doi.org/10.25299/sportarea.2020.vol5(1).4053 
How To Cite: Juliasti, E., Kuswari, M., \& Jus'at, I. (2020). Senam Irama Lagu Gizi Seimbang Meningkatkan Kebugaran Pada Anak Sekolah. Journal Sport Area, 5(1), 22-29.

\section{PENDAHULUAN}

Anak usia sekolah adalah investasi bangsa, karena mereka adalah generasi penerus bangsa. Tumbuh kembangnya anak usia sekolah yang optimal tergantung pemberian asupan zat gizi dengan kualitas dan kuantitas yang baik serta benar (Hardinsyah \& Aries, 2012). Masalah yang sering timbul terutama dalam pemberian makanan yang bergizi dan berimbang yang tidak benar dan menyimpang. Bukan hanya itu saja, terbiasa melakukan kegiatan dengan bantuan alat-alat yang serba praktis, sehingga menjadi mudah lelah ketika melakukan kegiatan fisik yang bersifat aktif (Mulyani, Kuswari, Sudikno, Sandjaja, \& Ernawati, 2016). Perilaku aktivitas fisik di Indonesia yang dikategorikan aktif tertinggi di Provinsi Bali $(85,8 \%)$ dan terendah di DKI Jakarta $(55,8 \%)$. Pusat Pengembangan Kualitas Jasmani Kementerian Pendidikan Nasional (PPKJKPN) 2010 melakukan tes kebugaran jasmani yang dilakukan di 17 Provinsi dari SD sampai SMA/SMK dengan subjek 12.240 siswa yang memiliki tingkat kebugaran jasmani yang baik hanya 17\%, sedang 38\% dan kurang 45\% (Depkes, 2018). Berbagai bentuk aktivitas fisik dapat dilakukan yaitu salah satunya dengan olahraga. Berbagai macam olahraga kesehatan yang dapat dilakukan di antaranya bersepeda, berlari, berenang, mendayung, senam dan berbagai macam olahraga lainnya (Kuswari \& Setiawan, 2015)

Senam Irama sebagai program peningkatan kebugaran jasmani siswa memiliki keunggulan-keunggulan khusus bila dibandingkan dengan kegiatan olahraga lainnya. Pentingnya kebugaran jasmani dimiliki setiap orang, terlebih utama bagi siwa antara lain dapat meningkatkan organ tubuh, sportivitas, semangat kompetisi (Alawiyah, Sugeng, \& Kuswari, 2015; Barkley, Ryan, Bellar, Bliss, \& Roemmich, 2011). Senam dan kebugaran berperan dalam perkembangan kemampuan fisik dan kemampuan gerak. Penelitian meta analisis pada 1276 responden yang melakukan latihan dance selama $>4$ minggu menunjukkan hasil yang efektif dilakukan untuk meningkatkan kesehatan dan kebugaran (Yan et al., 2018; Murphy et al., 2009; O’Neill, Pate, \& Hooker, 2011). Kebugaran merupakan kemampuan tubuh untuk melaksanakan suatu kegiatan dengan menggunakan kekuatan, daya kreasi, dan daya tahan dengan efisien dalam waktu yang relatif lama tanpa menimbulkan kelelahan berlebihan (Kuswari \& Setiawan, 2015). Kebugaran jasmani merupakan aspek fisik dari kesegaran yang menyeluruh yang memberikan kesanggupan kepada seseorang untuk menjalankan hidup produktif dan dapat menyesuaikan diri pada tiap pembebanan fisik yang layak kognitif individu. Tujuan penelitian adalah untuk mengidentifikasi senam terhadap tingkat kebugaran anak sekolah dasar.

\section{METODE PENELITIAN}

Dalam penelitian ini penulis ingin mengungkap pengaruh dari variabel tertentu. Penelitian ini dilakukan pada bulan Januari 2018. Jenis penelitian metode quasi eksperimental design dengan pre-test post-test control group design. Desain ini melibatkan dua kelompok subjek, satu diberi intervensi (kelompok eksperimen) dan satu kelompok tidak diberi apa-apa (kelompok kontrol). Lokasi pelaksanaan penelitian dilakukan di SD Negeri Kebon Jeruk 08 Jakarta. Sekolah ini terletak di Jalan Raya Kebon Jeruk No.41 RT 007 RW 01, Kecamatan Kebon Jeruk, Kota Jakarta Barat dengan jumlah siswa kelas V dan VI adalah 158 orang. 
Pada penelitian ini pengambilan responden dilakukan dengan teknik purposive sampling. Adapun jumlah responden dalam penelitian ini dihitung menggunakan rumus uji beda dua mean (paired) berdasarkan rumus (Lemeshow, Hosmer, Klar, Lwanga, \& Organization, 1990). Hasil perhitungan menunjukkan jumlah responden sebanyak 62 siswa yang dibagi menjadi 2 kelompok yaitu 31 siswa kelompok intervensi senam dan 31 siswa kelompok kontrol dengan usia responden 10-12 tahun). Pengumpulan data menggunakan wawancara, observasi dan dokumentasi. Instrumen penelitian menggunakan kuesioner untuk pengambilan data karakteristik responden, tingkat kebugaran menggunakan Tes Kebugaran Jasmani Indonesia (TKJI) yaitu lari 40 meter, gantung siku tekuk, Sit Up, Vertical Jump dan lari jarak menengah 600 meter (Alawiyah et al., 2015). Latihan senam dilakukan sebanyak 12 kali dan dilakukan 3x/minggu dengan media lagu gizi seimbang. Lagu gizi seimbang terdapat berisi tentang apa saja yang harus dilakukan setiap orang agar tubuhnya tetap sehat dan dapat beraktivitas dengan baik. Instrumen lain yaitu buku catatan, alat tulis, timbangan digital, microtoice dan alat Bioelectrical Impedance Analysis (BIA).

Analisa data yang dilakukan adalah univariat dan bivariat. Analisa univariat dilakukan dengan tingkat kebugaran, status gizi (IMT/U) dan bodyfat (persen lemak tubuh). Analisa bivariat dalam penelitian ini menggunakan uji t-test wilcoxon pada data yang tidak normal menggunakan untuk melihat pengaruh senam irama terhadap tingkat kebugaran pada anak sekolah.

\section{HASIL DAN PEMBAHASAN \\ Tingkat Kebugaran}

Hasil penelitian menunjukkan bahwa pada kelompok senam dari 30 orang siswa SD Negeri Kebon Jeruk 08 Jakarta tersebut memiliki median pretest tingkat kebugaran sebesar 14.00 \pm 0.345 . Tingkat kebugaran terendah berada yaitu 11 dan tingkat kebugaran tertinggi yaitu 18 sedangkan median posttest tingkat kebugaran memiliki skor sebesar $15.00 \pm 0.386$ dimana skor terendah 12 dan skor tertinggi 19. Distribusi tingkat kebugaran pada senam irama dapat dilihat di tabel 1.

Tabel 1. Distribusi Tingkat Kebugaran (Kelompok Senam) Siswa SD Negeri Kebon Jeruk 08 Jakarta

\begin{tabular}{lcccc}
\hline \multicolumn{1}{c}{ Tingkat Kebugaran } & Median & SE & Min & Maks \\
\hline Pretest & 14.00 & 0.345 & 11 & 18 \\
\hline posttest & 15.00 & 0.386 & 12 & 19 \\
\hline
\end{tabular}

Penelitian pada kelompok kontrol menunjukkan bahwa dari 30 orang siswa SD Negeri Kebon Jeruk 08 Jakarta tersebut memiliki median z-score status gizi sebesar $0.230 \pm 0.250$. Status gizi terendah berada pada $\mathrm{z}$-score yaitu -2.13 dan status gizi tertinggi berada pada $\mathrm{z}$-score 2.81 .

Tabel 2. Distribusi Tingkat Kebugaran (Kelompok Kontrol) Siswa SD Negeri Kebon Jeruk 08 Jakarta

\begin{tabular}{ccccc}
\hline Tingkat Kebugaran & Median & SE & Min & Maks \\
\hline Pretest & 14.00 & 0.305 & 10 & 18 \\
\hline Posttest & 14.00 & 0.294 & 10 & 18 \\
\hline
\end{tabular}




\section{Status Gizi}

Rata-rata status gizi siswa kelas 4 dan 5 di SD Negeri Kebon Jeruk 08 Pagi Jakarta Barat adalah pada kelompok senam dari 30 orang siswa SD Negeri Kebon Jeruk 08 Jakarta tersebut memiliki median $\mathrm{z}$-score status gizi sebesar $-0.085 \pm 0.218$. Dimana status gizi terendah berada pada $\mathrm{z}$-score yaitu -2.56 dan status gizi tertinggi berada pada z-score yaitu 2.53. Hasil ini menggambarkan bahwa terdapat siswa yang memiliki status gizi kurus dan juga siswa yang obesitas.

Kelompok kontrol dari 30 orang siswa SD Negeri Kebon Jeruk 08 Jakarta tersebut memiliki median $\mathrm{z}$-score status gizi sebesar $0.230 \pm 0.250$. Dimana status gizi terendah berada pada z-score yaitu -2.13 dan status gizi tertinggi berada pada z-score 2.81. hal ini menggambarkan bahwa terdapat siswa yang memiliki status gizi kurus dan juga siswa yang obesitas.

Tabel 3. Distribusi Status Gizi dan Bodyfat (Persen Lemak) Kelompok Senam Anak Sekolah SD Negeri Kebon Jeruk 08 Jakarta

\begin{tabular}{ccccc}
\hline Variabel & Median & SE & Min & Maks \\
\hline Status Gizi & -0.085 & 0.218 & -2.56 & 2.53 \\
\hline Persen Lemak & 15.65 & 1.004 & 6.8 & 30.4 \\
\hline
\end{tabular}

\section{Bodyfat (Persen Lemak Tubuh)}

Pada kelompok senam median persen lemak memiliki skor sebesar $15.65 \pm 1.004$ dimana skor terendah 6.8 dan skor tertinggi 30.4 sedangkan pada kelompok kontrol

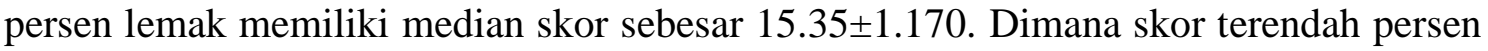
lemak yaitu 9.8 dan skor tertinggi persen lemak yaitu 35.4.

\section{Perbedaan Tingkat Kebugaran}

Tingkat kebugaran anak sekolah sebelum diberikan senam dan sesudah diberikan senam serta tingkat kebugaran pada kelompok yang tidak diberi perlakuan di SD Negeri Kebon Jeruk 08 Jakarta Barat. Analisis bivariat dilakukan untuk mengetahui pengaruh variabel yang diteliti. Variabel yang diteliti yaitu variabel independen pengaruh senam irama dengan variabel dependen yaitu tingkat kebugaran sebelum dan sesudah senam.

Tabel 4. Analisis Pengaruh Senam Terhadap Tingkat Kebugaran Anak Sekolah SD Negeri Kebon Jeruk 08 Jakarta Barat

\begin{tabular}{ccccccc}
\hline \multirow{2}{*}{$\begin{array}{c}\text { Tingkat } \\
\text { Kebugaran }\end{array}$} & \multicolumn{2}{c}{ Kelompok Senam } & & \multicolumn{2}{c}{ Kelompok kontrol } & \multirow{2}{*}{ pValue } \\
\cline { 2 - 6 } & Mean & SD & pValue & Mean & SD & \\
\hline Pretest & 14.47 & 1.889 & 0.0001 & 14.33 & 1.668 & \multirow{2}{*}{0.18} \\
\hline Posttest & 15.57 & 2.112 & 0.0012 & 1.23 & 1.612 & \\
\hline
\end{tabular}

Hasil uji statistik menunjukkan bahwa nilai rata-rata posttest memiliki peningkatan hasil tes kebugaran dibandingkan dengan nilai rata-rata pretest. Hasil ini dapat dilihat bahwa terdapat perbedaan rata-rata pretest kelompok senam. Terdapat pengaruh yang bermakna senam irama terhadap tingkat kebugaran pada anak sekolah di SD Negeri Kebon Jeruk 08 Jakarta Barat dengan nilai $\mathrm{p}=0,0001(\mathrm{p}<0,05)$. Pada kelompok kontrol terdapat penurunan hasil tes akhir kebugaran dibandingkan dengan tes awal yang dilakukan. 
Usia responden pada penelitian ini berkisar antara 10 hingga 12 tahun yang sebagian besar responden berusia 10 tahun pada kedua kelompok tersebut. Kemampuan motorik berkaitan dengan proses tumbuh kembang dimana perkembangan gerak seorang anak usia 10-12 tahun dipengaruhi oleh aktivitas fisiknya. Pada dasarnya, kemampuan ini berkembang sejalan dengan kematangan syaraf dan otak. Sehingga setiap gerakan sederhana apapun merupakan hasil pola interaksi yang kompleks dari berbagai bagian sistem dalam tubuh yang dikontrol dalam otak (Amado, Sánchez-Miguel, \& Molero, 2017).

Anak usia sekolah mempunyai pertumbuhan dan perkembangan yang cepat, istilah tumbuh kembang mencakup dua peristiwa yang sifatnya berbeda, tetapi saling berkaitan dan sulit dibedakan, yaitu pertumbuhan dan perkembangan. (Usfar et al., 2009). Status gizi normal dengan indikator z-score IMT/U anak usia sekolah berada pada -2 s/d 2 Standar Deviasi (SD). Kelompok Senam, dilihat tabel 4.5 dapat diketahui bahwa yang telah dilakukan terhadap responden, didapatkan hasil median kelompok senam z-score status gizi dimana hasil tersebut termasuk dalam kategori status gizi normal. Kelompok kontrol, dilihat tabel 4 menunjukkan bahwa yang telah dilakukan terhadap responden didapat median z-score status gizi dimana hasil tersebut termasuk dalam kategori normal.

Berdasarkan hasil pengukuran berat badan dan tinggi badan siswa SD Negeri Kebon Jeruk 08 Jakarta dapat diketahui bahwa rata-rata status gizi kelompok senam maupun kelompok kontrol responden terbilang dalam kategori normal. Namun, masih terlihat $z-$ score di bawah -2 SD atau dengan kata lain sangat kurus dan di atas $>1$ SD yang berarti gemuk. Hasil uji statistik penelitian juga menunjukkan nilai $\mathrm{p} \leq 0,05$, maka terdapat pengaruh yang signifikan pada tingkat kebugaran pada anak sekolah sebelum dan setelah diberikan intervensi yaitu senam.

Status gizi normal adalah suatu keadaan dimana terdapat keseimbangan asupan dengan kebutuhan zat gizi yang digunakan untuk beraktivitas sehari-hari. Status gizi kurus terjadi apabila zat gizi diperoleh dalam jumlah yang kurang (Verjans-Janssen, Van de Kolk, Van Kann, Kremers, \& Gerards, 2018). Status gizi merupakan gambaran keseimbangaan antara asupan (intake) dan kebutuhan (requirement) zat gizi untuk berbagai proses biologis tubuh. Status gizi yang dinyatakan dengan Indeks Massa Tubuh mempunyai hubungan yang negatif dengan tingkat kebugaran, yang berarti semakin tinggi nilai IMT maka semakin rendah skor tes kebugaran tubuhnya (Setiowati, 2014). Hasil penelitian menunjukkan terjadi penurunan persen lemak tubuh pada kelompok senam dan kelompok kontrol dapat diketahui.

Penelitian dilakukan Dewi, Kustiyah, dan Kuswari (2015) menunjukkan bahwa semakin tinggi persen lemak tubuh seorang anak maka semakin rendah tingkat kebugaran jasmaninya sehingga dapat disimpulkan bahwa tingkat kesegaran jasmani anak obesitas rata-rata lebih rendah dibandingkan dengan anak normal. Sebaliknya tingkat kesegaran jasmani akan meningkat dengan adanya peningkatan hemoglobin dan aktivitas fisik. Melakukan kegiatan fisik dan olahraga secara baik, teratur dan terus menerus bermanfaat dalam mencapai status kebugaran jasmani yang optimal. Latihan yang teratur dapat meningkatkan kebugaran jasmani. Peningkatan yang diperoleh antara lain: peningkatan gerak, tidak mudah Lelah dan peningkatan keterampilan (Kuswari \& Gifari, 2020).

Penelitian ini sejalan dengan penelitian yang dilakukan oleh Yusuf (2013) yang meneliti tentang pengaruh latihan senam aerobik terhadap tingkat kebugaran jasmani 
siswa putri kelas VII SMP Kartika XII-I Mertoyudan Magelang. Hasil penelitian menunjukkan bahwa terdapat pengaruh latihan senam aerobik terhadap tingkat kebugaran jasmani siswa putri kelas VII SMP Kartika XII-I Mertoyudan Magelang. Hal ini dibuktikan dengan beda rerata atau mean kelompok pretest 14,20 dan post test 18,05. Dari hasil perhitungan menggunakan statistik maka didapatkan ada pengaruh secara signifikan antara tingkat kebugaran sebelum dan sesudah diberikan senam dengan nilai pvalue $=0,000$.

Hasil penelitian ini juga sejalan dengan penelitian Kunarti (2014) pada anak Sekolah Menengah Pertama (SMP), latihan senam irama yang dilakukan seminggu 2x selama 12 kali dapat meningkatkan kebugaran jasmani. Hasil penelitian pada 265 anak sekolah dasar kelas 5 menunjukkan bahwa olahraga senam yang dilakukan secara rutin dapat meningkatkan aktivitas fisik dan kebugaran anak (Chen, Hammond-Bennett, Hypnar, \& Mason, 2018). Penelitian meta analisis yang dilakukan pada 25 penelitian pada anak usia 4-12 tahun menunjukkan bahwa intervensi olahraga di sekolah terbukti dapat meningkatkan aktivitas fisik dan kebugaran serta memperbaiki status gizi.

\section{KESIMPULAN}

Hasil penelitian menunjukkan bahwa latihan senam gizi seimbang dapat meningkatkan kebugaran anak sekolah dibandingkan dengan kelompok kontrol. Anak usia sekolah berada pada tahap pertumbuhan dan perkembangan yang membutuhkan banyak aktivitas olahraga sebagai penunjang proses tersebut. Oleh karena itu olahraga senam dapat menjadi salah satu program di sekolah yang berperan terhadap perkembangan gerak dan kemampuan fisik anak sekolah.

\section{DAFTAR PUSTAKA}

Alawiyah, T., Sugeng, W., \& Kuswari, M. (2015). Status Gizi, Asupan Zat Gizi Makro Serta Serat, dan Aktivitas Fisik Dengan Kebugaran Anak Sekolah Dasar Kelas V Usia (10-12 Tahun) di SDN Talaga 2 Cikupa Tangerang. NUTRIRE DIAITA, 7(1).

Amado, D., Sánchez-Miguel, P. A., \& Molero, P. (2017). Creativity associated with the application of a motivational intervention programme for the teaching of dance at school and its effect on the both genders. PloS One, 12(3), 1-14. e0174393e0174393. https://doi.org/10.1371/journal.pone.0174393

Barkley, J. E., Ryan, E. J., Bellar, D., Bliss, M. V, \& Roemmich, J. N. (2011). The Variety of Exercise Equipment and Physical Activity Participation in Children. Journal of Sport Behavior, 34(19), 137-149.

Chen, W., Hammond-Bennett, A., Hypnar, A., \& Mason, S. (2018). Health-related physical fitness and physical activity in elementary school students. BMC Public Health, 18(1), 195. https://doi.org/10.1186/s12889-018-5107-4

Depkes. (2018). Laporan Hasil Riset Kesehatan Nasional 2018. Jakarta. 
Dewi, M., Kustiyah, L., \& Kuswari, M. (2015). Percent Fat Mass and Body Mass Index as Cardiorespiratory Fitness Predictors in Young Adults. Jurnal Gizi dan Pangan. 10(3), 179-184. https://doi.org/10.25182/jgp.2015.10.3.\%p.

Hardinsyah, \& Aries, M. (2012). Jenis Pangan Sarapan dan Perannya Dalam Asupan Gizi Harian. Jurnal Gizi dan Pangan, 7(2), 89-96. https://doi.org/10.25182/jgp.2012.7.2.89-96.

Kunarti, T. U. (2014). Pengaruh Latihan Senam Irama terhadap Peningkatan Kebugaran Jasmani terhadap Siswa-siswi Kelas VII SMP Negeri 2 Abung Tengah Lampung Utara Tahun Ajaran 2013/2014. (Doctoral dissertation, Fakultas Keguruan dan Ilmu Pendidikan).

Kuswari, M., \& Gifari, N. (2020). Periodisasi Gizi dan Latihan. Rajagrafindo Persada.

Kuswari, M., \& Setiawan, B. (2015). Frekuensi Senam Aerobik Intensitas Sedang Berpengaruh Terhadap Lemak Tubuh Pada Mahasiswa IPB. Jurnal Gizi Pangan, 10(1), 25-32. https://doi.org/10.25182/jgp.2015.10.1.\%25p.

Lemeshow, S., Hosmer, D. W., Klar, J., Lwanga, S. K., \& Organization, W. H. (1990). Adequacy of sample size in health studies. Chichester: Wiley.

Mulyani, E. Y., Kuswari, M., Sudikno, Sandjaja, \& Ernawati, F. (2016). Limitations in vitamin A supplementation to optimise serum retinol in preschool children from two central Java districts. Asia Pacific Journal of Clinical Nutrition, 25, 30-35. https://doi.org/10.6133/apjen.122016.s8

Murphy, E. C.-S., Carson, L., Neal, W., Baylis, C., Donley, D., \& Yeater, R. (2009). Effects of an exercise intervention using Dance Dance Revolution on endothelial function and other risk factors in overweight children. International Journal of Pediatric Obesity : IJPO : An Official Journal of the International Association for the Study of Obesity, 4, 205-214. https://doi.org/10.3109/17477160902846187

O’Neill, J. R., Pate, R. R., \& Hooker, S. P. (2011). The contribution of dance to daily physical activity among adolescent girls. International Journal of Behavioral Nutrition and Physical Activity, 8, 8. https://doi.org/10.1186/1479-5868-8-87

Setiowati, A. (2014). Hubungan Indeks Massa Tubuh, Persen Lemak Tubuh, Asupan Zat Gizi dengan Kekuatan Otot. Jurnal Media Ilmu Keolahragaan Indonesia, 4(1). 31-38. https://doi.org/10.15294/miki.v4i1.4394.

Usfar, A. A., Achadi, E. L., Martorell, R., Hadi, H., Thaha, R., Jus'at, I., ... Soekirman. (2009). Expert meeting on child growth and micronutrient deficiencies - New initiatives for developing countries to achieve millennium development goals: executive summary report. Asia Pacific journal of clinical nutrition, 18(3), 462469. 
Verjans-Janssen, S. R. B., Van de Kolk, I., Van Kann, D. H. H., Kremers, S. P. J., \& Gerards, S. M. P. L. (2018). Effectiveness of school-based physical activity and nutrition interventions with direct parental involvement on children's BMI and energy balance-related behaviors-A systematic review. PLOS ONE, 13(9), 1-24. e0204560. Retrieved from https://doi.org/10.1371/journal.pone.0204560

Yan, A. F., Cobley, S., Chan, C., Pappas, E., Nicholson, L. L., Ward, R. E., ... Hiller, C. E. (2018). The Effectiveness of Dance Interventions on Physical Health Outcomes Compared to Other Forms of Physical Activity: A Systematic Review and MetaAnalysis. Sports Medicine, 48(4), 933-951. https://doi.org/10.1007/s40279-0170853-5

Yusuf, J. B. K. (2013). Pengaruh senam aerobik terhadap tingkat kebugaran jasmani siswa putri kelas VII SMP Kartika XII-I Mertoyu dan Magelang. Thesis, Universitas Negeri Yogyakarta. 